\title{
IDENTIFICATION OF CORAL REEF CONDITIONS IN SUNGAI CUKA VILLAGE, KINTAP DISTRICT OF TANAH LAUT REGENCY, SOUTH KALIMANTAN PROVINCE OF INDONESIA
}

\author{
Frans Tony ${ }^{\star}$, Ahsin Rifa'l M. \\ Department of Marine Science, Faculty of Fisheries and Marine Science, \\ University of Lambung Mangkurat, South Kalimantan, Indonesia
}

\section{Syamsu Hidayat Achmad}

Department of Fishery Agribusiness Program Study, Faculty of Fisheries and Marine Science, Universitas Lambung Mangkurat, South Kalimantan, Indonesia

\author{
Rina Iskandar \\ Department of Fisheries, Faculty of Agriculture, University of Achmad Yani Banjarmasin, \\ South Kalimantan, Indonesia \\ *E-mail: ftony@ulm.ac.id
}

\begin{abstract}
Tanah Laut Regency has a very strategic potential in tourism development in South Kalimantan Province, so it is deemed necessary to conduct underwater research with the aim of identifying coral reef types, knowing the condition of coral cover and knowing the physical and chemical conditions of the waters of the SungaiCuka Village, Kintap District. Coral reef ecosystems around the waters of Sungai Cuka village, KintapDistrict only found 1 type of Acropora coral lifeform, namely Acropora tabulate (ACT), and 4 Non-Acropora species namely Coral branching (CB), Coral massive (CM), Coral encrusting (CE), Coral foliose (CF), Coral reef cover range survival ranged from $1.88 \%$ to $46.38 \%$. Therefore, the condition of coral reefs around the sea waters of Sungai Cuka Village, Kintap District ranges from low to fair based on coral reef assessment criteria according to Indonesia Environment Minister's Decree, No. 4/2011. Almost all water quality parameters measured: temperature, brightness, current speed, salinity, $\mathrm{pH}$ and $\mathrm{DO}$ are still within the tolerance limits of water quality standards, except for brightness which is below the quality standard threshold, which is between $3-3.5$ meters and salinity which ranges from $35-40$ above the quality standard threshold based on the IndonesiaEMinister of Environment Decree No. 51/2004.
\end{abstract}

\section{KEY WORDS}

Coral reef, Sungai Cuka village, Tanah Laut regency, South Kalimantan province.

Tanah Laut Regency has a very strategic potential in tourism development in South Kalimantan Province, one of which is the potential for underwater tourism which was recently discovered by the Potential Excavation Team of the Tanah Laut Regency Tourism Office in collaboration with a team of divers from the Faculty of Fisheries and Marine Affairs, Lambung Mangkurat University in in 2019 in Sungai Cuka Village, Kintap District, Tanah Laut Regency. From the initial identification, several coral reef spots were found at coordinates $S$ 03 $52^{\prime}$

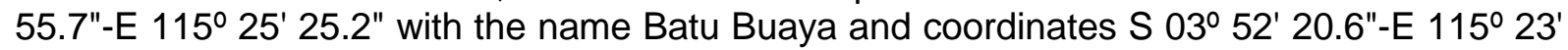
51.3" named Batu Gagak. Reef fish are important communities in coral reef ecosystems because of their trophic relationship with other biotic components (Tony. F, et al 2021, Rifa'i, 2016; Rifa'i, et al, 2016, Iskandar. R, et al 2020)

Based on Law Number 23 of 2014 concerning Regional Government and Regional Regulation Number 13 of 2018 concerning the division of water zoning in South Kalimantan, it is stated that from the coastline to 12 miles the management of marine spatial planning is the authority of the South Kalimantan Provincial government. Meanwhile, based on Law no. 10 of 2009 concerning tourism, requires that tourism development in districts/cities refers to 
national, regional and local interests. The main ideas are based on local interests, namely related that regional tourism development planning must reflect regional autonomy, through efforts to optimize the utilization of regional potential and resources. In addition, regional tourism development must also pay attention to the preservation of nature and the environment diversity of reef fish in the sea waters of Sungai Cuka Village, Kintap District, Tanah Laut Regency, South Kalimantan. The role of the government is very important in managing the utilization of coastal potential and empowering coastal village communities to support the development of diversifying their business (Hidayat A. S., and Agusliani, E., 2020).

On the basis of these considerations, as well as referring to the tourism potential to dig deeper related to the underwater potential found in Sungai village. It is deemed necessary to conduct research on Identification of Reef Conditions in SungaiCuka Village, Kintap District, Tanah Laut Regency, South Kalimantan Province with the aim of identifying coral reef types, knowing the condition of coral cover and knowing the physical and chemical conditions of water in the Sea waters of Sungai Cuka Village, Kintap District.

\section{METHODS OF RESEARCH}

The material of this research is coral reefs in the waters of SungaiCuka Village, Kintap District, South Kalimantan Province with several environmental parameter data including bioecological aspects consisting of live coral cover and coral lifeforms, physical aspects consisting of Temperature $\left({ }^{\circ} \mathrm{C}\right)$, Brightness $(\mathrm{m})$, Current $(\mathrm{m} / \mathrm{s})$ and chemical aspects involved. consists of Salinity (\%o), Degree of Acidity $(\mathrm{pH})$ and Dissolved Oxygen (DO). As a brief description of the observation points, it can be seen in Figure 1 below:

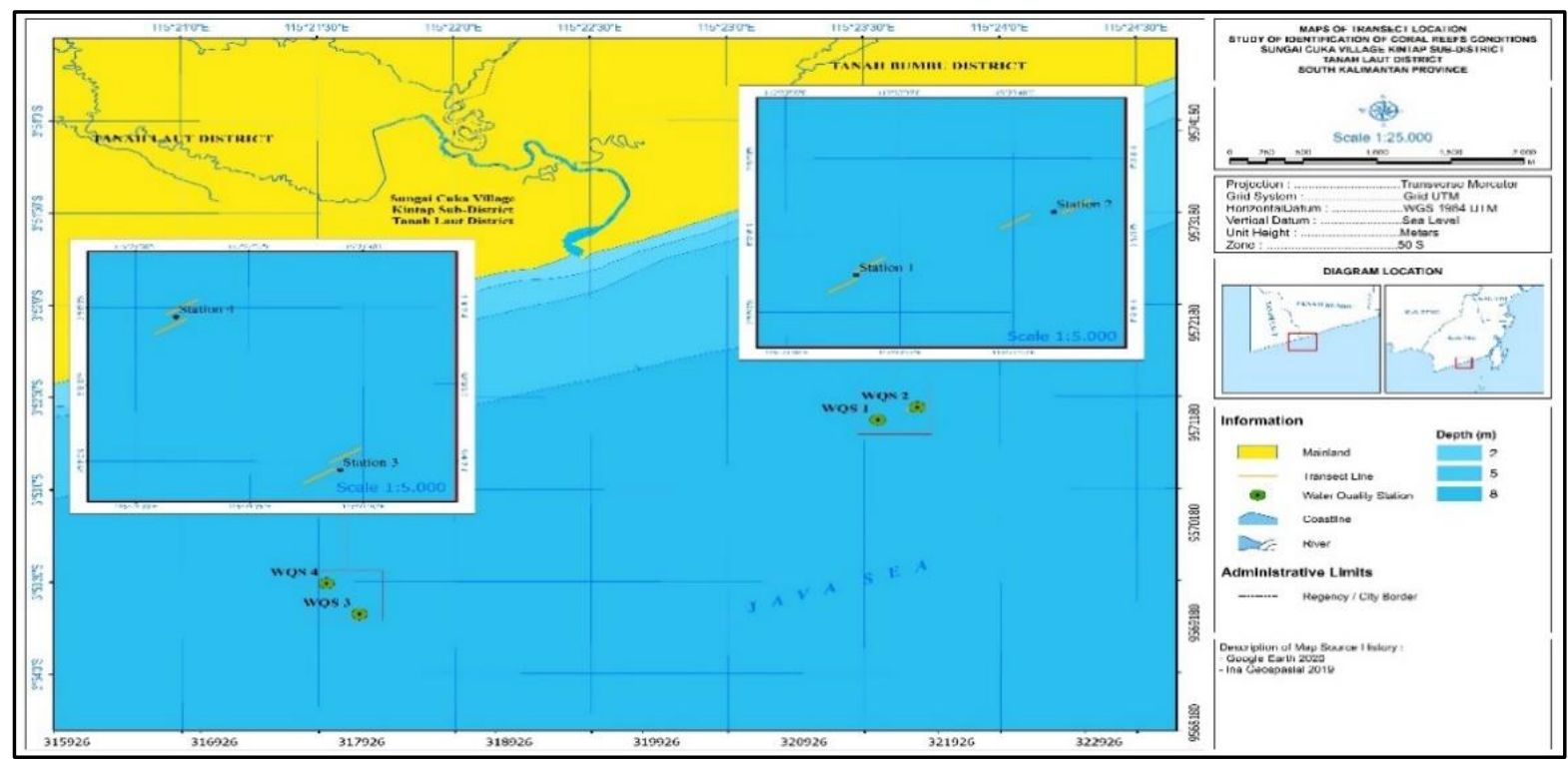

Figure 1 - Research Location Map

The research method in collecting data on coral reefs uses the Line Intercept Transect (LIT) method based on English et al, (1997). Reef fish data was collected using the Underwater Visual Census (UVC) method (English et al, 1994).

Determination of Research Stations and Parameters. Determination of the research station point is done by purposive sampling technique. The technique is based on the consideration that the selected location can represent the waters of the marine waters of Sungai Cuka Village, Kec. Kintap. Coral community data collection consisted of 4 stations which were determined purposively. By being marked using the help of GPS (Global Position System). Each station consists of 2 (two) transects while for water quality parameters taken at these stations. 
Table 1 - Research Station Coordinates

\begin{tabular}{|c|c|c|c|c|}
\hline Description & Station (ST) 1 & Station (ST) 2 & Station (ST) 3 & Station (ST) 4 \\
\hline \multirow{2}{*}{ Coordinates } & $03^{\circ} 52^{\prime} 37,6^{\prime \prime}$ & $03^{\circ} 52^{\prime} 33,5^{\prime \prime}$ & $03^{\circ} 53^{\prime} 40,6^{\prime \prime}$ & $03^{\circ} 53^{\prime} 30,6^{\prime \prime}$ \\
& $115^{\circ} 23^{\prime} 33,3^{\prime \prime}$ & $115^{\circ} 23^{\prime} 42,0^{\prime \prime}$ & $115^{\circ} 21^{\prime} 39,2^{\prime \prime}$ & $115^{\circ} 21^{\prime} 32,0^{\prime \prime}$ \\
\hline
\end{tabular}

The percentage of live coral cover, dead coral and other lifeform types is calculated using the formula (English et. al., 1997):

$$
\mathrm{C}=\frac{\alpha}{A} \times 100 \%
$$

Where: $\mathrm{C}=$ Percentage of closing lifeform $\mathrm{i} ; \alpha=$ Lifeform transect length $\mathrm{i} ; \mathrm{A}=$ Total length of transect.

Assessment of coral reef ecosystems refers to the Minister of Environment Decree No. 4 in 2011.

Temperature and $\mathrm{pH}$ were measured with the same tool so that data were obtained at once, namely using a water quality checker, the method of collecting data before using the tool was calibrated first. Temperature and $\mathrm{pH}$ were measured above the water surface at each predetermined station. Insert the tool into the surface of the water and record the data for each parameter that is read on the screen.

Water brightness data collection is carried out on the surface. The following are the steps for measuring the brightness of the waters:

- Dip the secchi disk into the water slowly until you don't see the black and white plates then record how deep the secchi disk goes into the water $(\mathrm{H} 1)$;

- Try not to shake too much so that the secchi disk remains flat;

- Lift the secchi disk slowly until the black and white plate is visible then note how deep the secchi disk goes into the water $(\mathrm{H} 2)$.

The measurement of brightness obtained by using the secchi disk (in meters) is processed to obtain the percentage value (\%) of the brightness of the waters with the equation:

$$
I=\frac{\left(\frac{\left(H_{1}+H_{2}\right)}{2}\right)}{H_{t o t}} \times 100 \%
$$

Where: $\mathrm{I}=$ water brightness (\%); $\mathrm{H} 1$ = secchi disk depth to invisible $(\mathrm{m}) ; \mathrm{H} 2$ = secchi disk depth when visible $(\mathrm{m}) ; \mathrm{H}_{\mathrm{tot}}=$ total water depth $(\mathrm{m})$.

Current velocity is measured using a current kite. Following are the steps in measuring the current velocity:

1. Dip the kite stream into the water;

2. Turn on the timer just after the current kite enters the water;

3. Observe the current kite until it reaches the maximum rope length (5 meters);

4. After reaching the maximum limit, stop the timer and record the time.

To find out the value of the current velocity at each station, the following equation is used:

$$
V=\frac{L}{p}
$$

Where: $V=$ current speed $(\mathrm{m} / \mathrm{s}) ; \mathrm{L}=$ length of the stretched rope $(\mathrm{m}) ; \mathrm{p}=$ time taken until the rope is stretched $(\mathrm{m})$.

Salinity is the amount of natural salt (grams) contained in one liter of seawater, usually expressed by per mile (\%o) or per thousand which indicates how many grams of mineral content in every 1,000 grams of seawater. Salinity was measured using a refractometer. The water sample is dropped into the refractometer, then the instrument is directed towards the sun directly, a blue and white field will appear, the boundary line between the two fields that shows the salinity level. Record the salinity value. 
Dissolve Oxygen (DO) is the level of oxygen in the water. The dissolved oxygen comes from the atmosphere directly which can then be utilized by aquatic biota. DO is also a benchmark to determine whether or not a water is good. The greater the DO value contained, the better the water quality. How to use the DO Meter is very easy, namely dip the pen on the DO meter into the water, and then the dissolved oxygen value will automatically be seen on the DO meter monitor.

\section{RESULTS AND DISCUSSION}

The results showed that there was 1 type of Acropora coral lifeform in the sea waters of SungaiCuka Villageis Acropora tabulate (ACT), and 4 types of Non-Acropora namely Coral branching (CB), Coral massive (CM), Coral encrusting (CE), Coral foliose (CF), Coverage range of live coral reefs ranges from $1.88 \%$ up to $46.38 \%$. Therefore, the condition of coral reefs around the waters of the village of Sungai Cuka Village, Kintap District ranged from low to fair.

Table 2 - Percentage of live coral cover in the waters of SungaiCuka Village -Kintap District

\begin{tabular}{|c|c|c|c|c|}
\hline Station & 1 & 2 & 3 & 4 \\
\hline Percentage (\%) & 46.38 & 41.14 & 14.14 & 1.88 \\
\hline
\end{tabular}

At station 1, transect 1 and transect 2 no hard coral (Acropora) cover was found, while hard coral (Non Acropora) was found at $22.98 \%$ and $23.3 \%$, respectively, while the hard coral category (Non Acropora) was found in eachtransect is Massive and Encrusting.

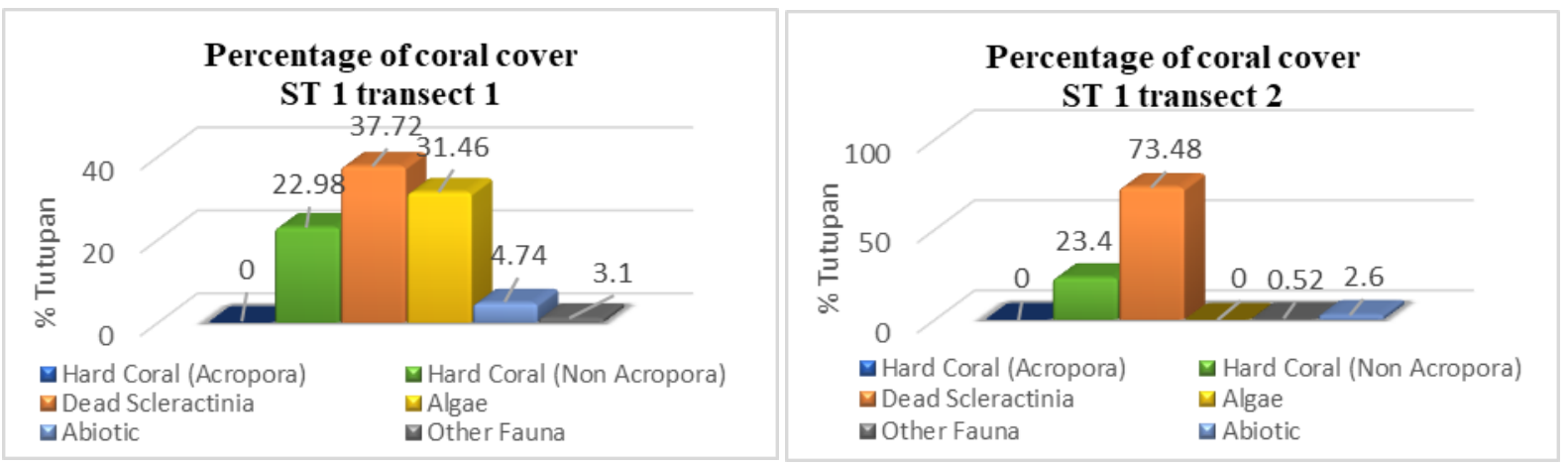

Figure 2 - Percentage of Coral Cover Station 1 transects 1 and 2.

The percentage of lifeform cover at Station 1 transect 1 found 6 species, namely Massive, Encrusting, DC with Algae, Halimidae, Sponge and Rubble, while at transect 2 found 5 species, namely Massive, Encrusting, DC with Algae, Sponge and Rubble.
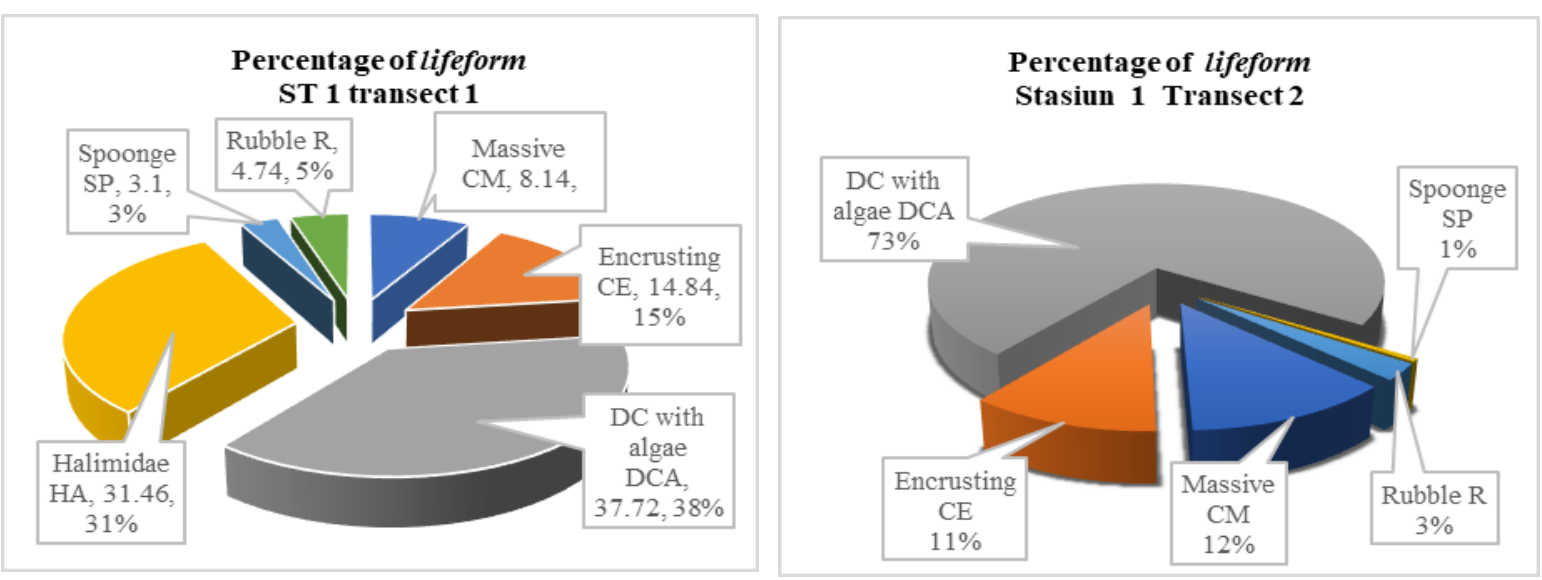

Figure 3 - Percentage of Lifeform Coverage for Station 1 transects 1 and 2. 
At station 2, the cover of hard coral (Acropora) namely Acropora tabulate (ACT) was only on transect 1, while hard coral (Non Acropora) were found to be $31.14 \%$ and $9.16 \%$, respectively, namely Massive and Encrusting species.

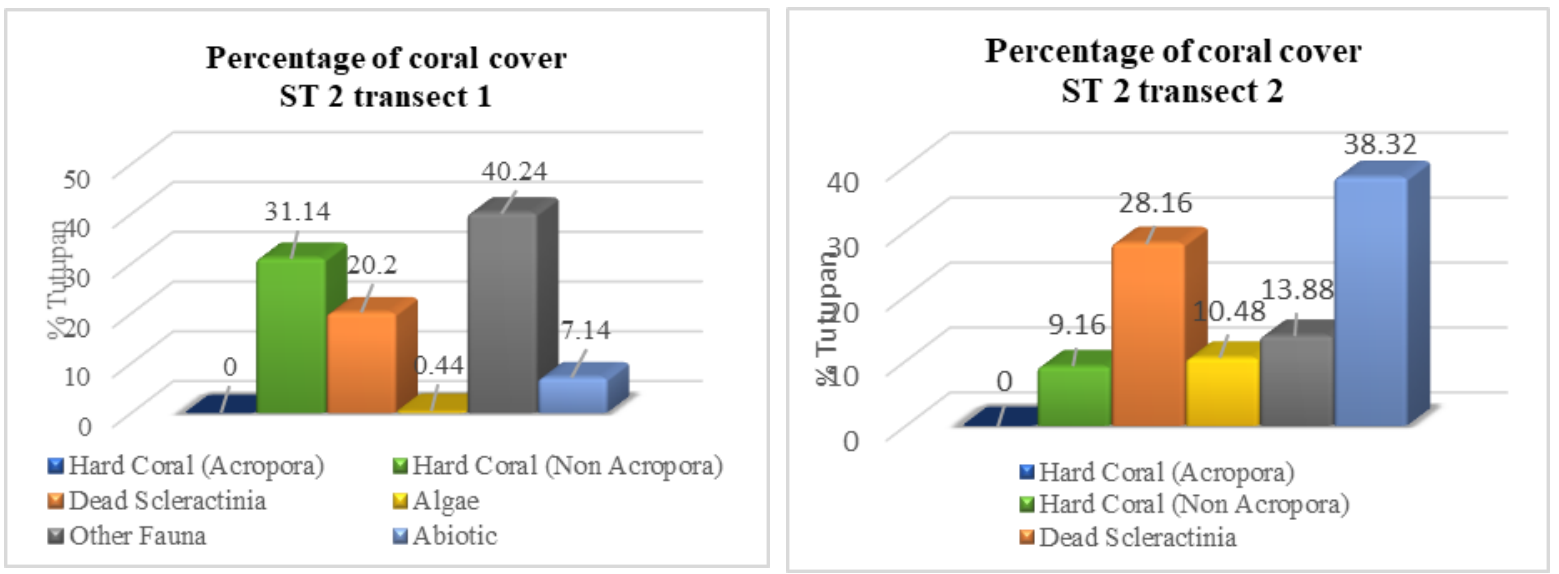

Figure 4 - Percentage of Coral Cover Station 2 transects 1 and 2

The percentage of lifeform cover at Station 2 transect 1 found 9 species, namely Tabulate, Branching, Massive, Encrusting, Foliose, DC With Algae, Halimidae, Sponge and Sand, while on transect 2 found 5 species namely Foliose, DC With Algae, Halimidae, Sponge and Sands.
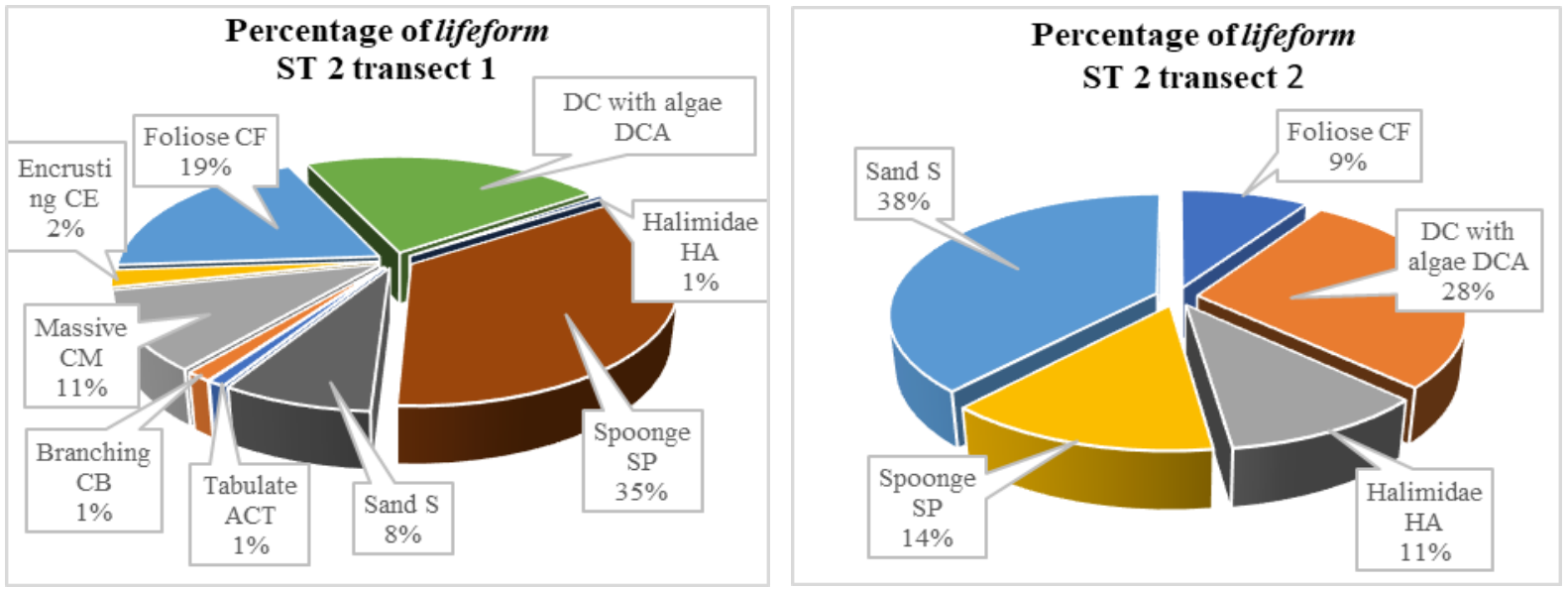

Figure 5 - Percentage of Lifeform Coverage for Station 2 transects 1 and 2
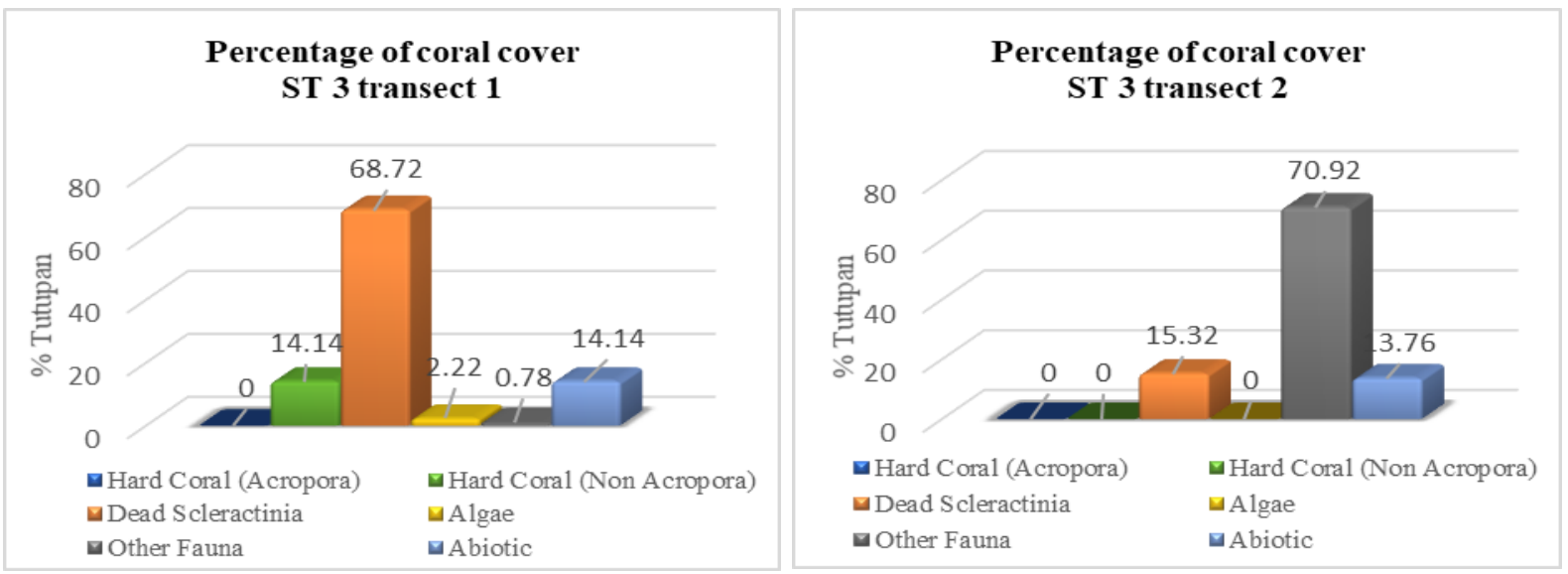

Figure 6 - Percentage of Coral Cover Station 3 transects 1 and 2 
At station 3, transect 1 and transect 2 did not find hard coral (Acropora) cover while hard coral (Non Acropora) was only found on transect 1, namely Massive and Foliose with a cover percentage of $14.14 \%$.

The percentage of lifeform cover at Station 3 transect 1 found 6 species, namely Massive, Foliose, DC With Algae, Halimidae, Sponge and Sand, while on transect 2 only 3 species were found, namely DC With Algae, Sponge and Sand.
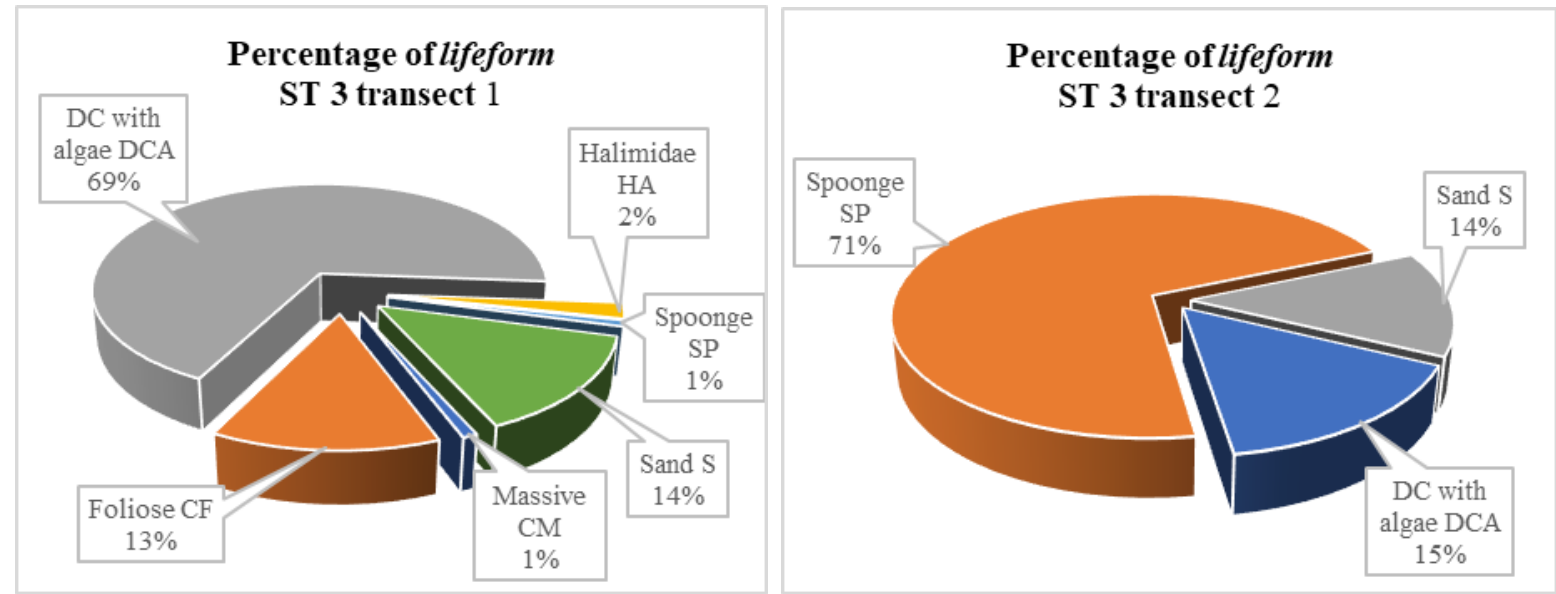

Figure 7 - Percentage of Lifeform Cover Station 3 transects 1 and 2
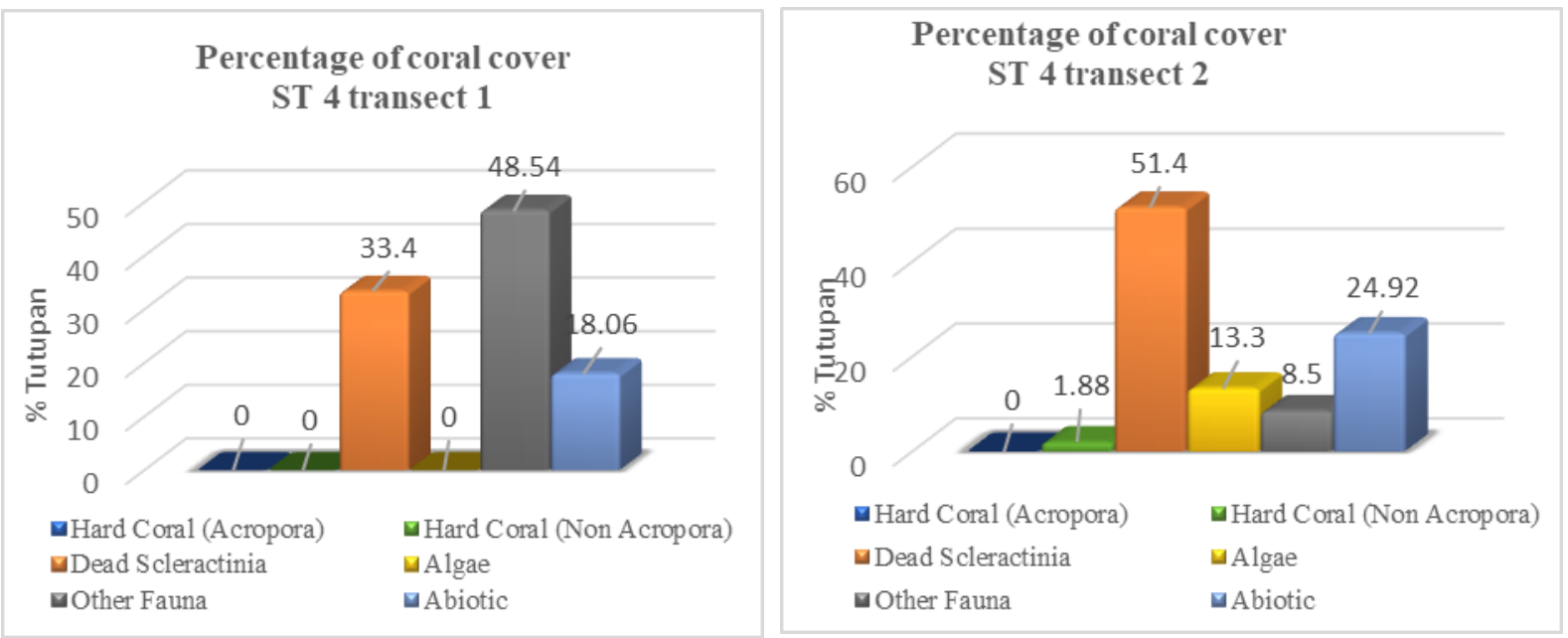

Figure 8 - Percentage of Coral Cover Station 4 transects 1 and 2
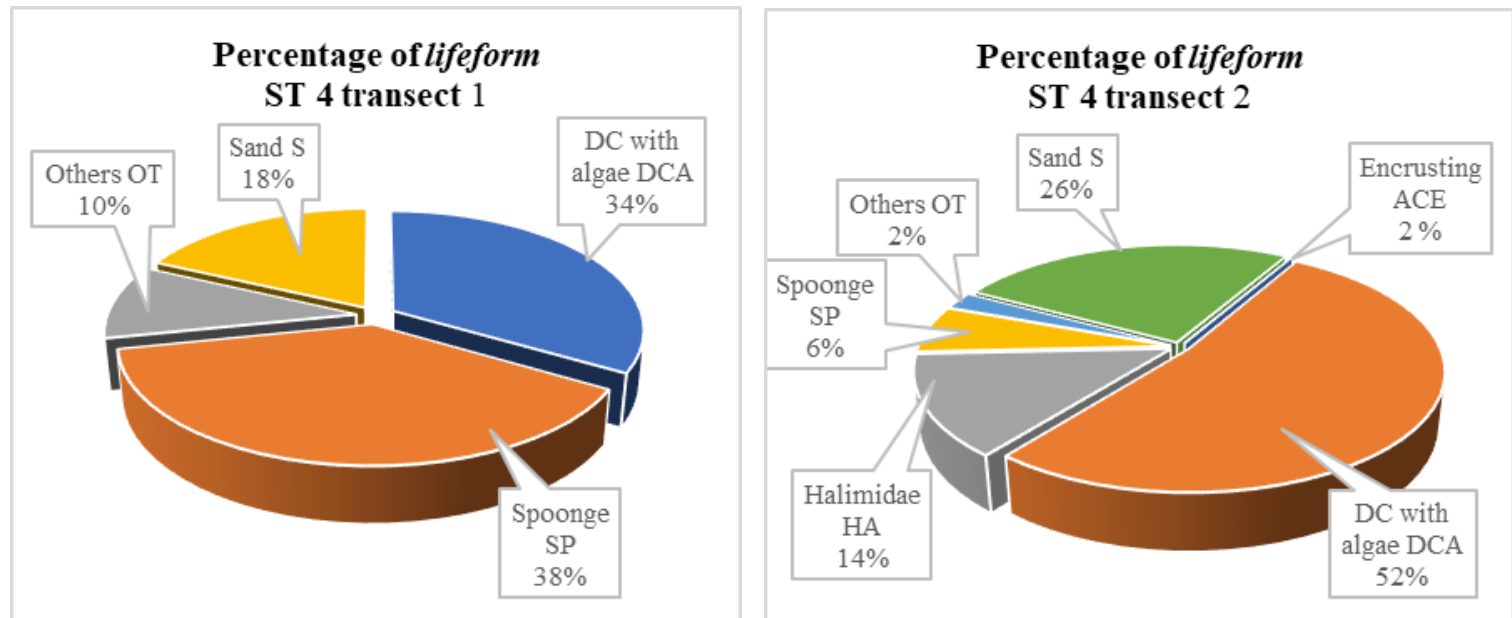

Figure 9 - Percentage of Lifeform Coverage for Station 4 transects 1 and 2 
At station 4, transect 1 and transect 2 did not find hard coral (Acropora) cover while hard coral (Non Acropora) was found on transect 2, namely Encrusting, with a cover percentage of $1.88 \%$.

The percentage of lifeform cover at Station 4 transect 1 found 4 species, namely DC With Algae, Sponge, Others and Sand, while on transect 2 found 6 species, namely Encrusting, DC With Algae, Halimidae, Sponge, Others and Sand.

The results of the research on water quality parameters which are physical and chemical factors in the sea waters of SungaiCuka Village, KintapDistrictcan be seen in table 4 below:

Table 3 - Measurement results of water quality parameters

\begin{tabular}{|c|c|c|c|c|c|c|}
\hline \multirow{2}{*}{\multicolumn{2}{|c|}{ Parameters }} & \multicolumn{4}{|c|}{ Stations } & \multirow{3}{*}{$\begin{array}{c}\text { Indonesia Environment Minister's } \\
\text { DecreeNo. 51/2004 }\end{array}$} \\
\hline & & 1 & 2 & 3 & 4 & \\
\hline \multicolumn{2}{|c|}{ Sampling Time } & 14.14 & 16.20 & 15.20 & 14.15 & \\
\hline \multirow{3}{*}{ Physical Factor } & Temperature $\left({ }^{\circ} \mathrm{C}\right)$ & 29 & 28 & 31 & 29 & $28-30^{\circ} \mathrm{C}$ \\
\hline & Brightness (m) & 3.5 & 3.3 & 5.2 & 3 & $>5$ \\
\hline & Current (m/s) & 0.05 & 0.08 & 0.10 & 0.08 & \\
\hline \multirow{3}{*}{ Chemical Factor } & Salinity (\%o) & 35 & 35 & 40 & 40 & $33-34$ \\
\hline & $\mathrm{pH}$ & 6.26 & 7.97 & 8.04 & 8.01 & $7-8.5$ \\
\hline & $\mathrm{DO}(\mathrm{mg} / \mathrm{l})$ & 6.4 & 7.8 & 5.9 & 5.8 & $>5$ \\
\hline
\end{tabular}

From the results of research activities, it can be concluded that the coral reefs in the waters of Sungai Cuka Village, KintapDistrict is a type of fringing coral reef, because coral reefs in the research location can be found along the coast with water depths not too far leading to the open sea which can be found at a depth of less than 8 meters. This is in line with the Nybakken (1988) which states that the Fringing Reef is a coral reef that is found along the coast and is not more than 40 meters deep. These reefs grow to the surface and towards the open sea. At the research location which is in the waters of Sungai Cuka Village, Kintap District, the average coral reef at this location is generally found to be sloping average at each station. At a depth of more than 8 meters, corals are rarely found; this is because the substrate of sand mixed with mud seems to dominate at the study site. In the sea waters of Sungai Cuka Village, Kintap District is known that the percentage of live coral cover is $46.38 \%$ which is in the fair category. The types of corals encountered were Coral Massive and Coral Encrusting.

Table 4 - Percentage of live coral cover in the waters of Sungai Cuka village, Kintap District

\begin{tabular}{|c|c|c|c|c|}
\hline Station & 1 & 2 & 3 & 4 \\
\hline Percentage (\%) & 46.38 & 4.14 & 14.14 & 1.88 \\
\hline Category & Fair & Fair & Low & Low \\
\hline
\end{tabular}

Table 5 - Coral Reef Assessment Criteria according to Indonesia Environment Minister's Decree No. 4/2011

\begin{tabular}{|c|c|}
\hline Category & Lifeform Coverage (\%) \\
\hline Very good & $75-100$ \\
\hline Well & $50-74.9$ \\
\hline Fair & $25-49.9$ \\
\hline Low & $0-24.9$ \\
\hline
\end{tabular}

Hard coral cover as an indicator of coral reef health looks low at each station, so the coral reefs are in Low condition. Coral reefs are strongly dominated by soft coral communities, hard corals generally from the Massive coral group and the growth of Halimeda algae. Other biota from the sponge group associated with other reefs is often seen reaching $71 \%$. According to Gomez \& Alcala (1982) the presence of algae will become competitors for corals so that corals are difficult to survive.

The low coral cover is also influenced by water quality including salinity which has exceeded the quality standard threshold based on the Indonesia Environment Minister's 
DecreeNo. 51/2004 with a salinity tolerance of $33-34 \%$, while at the time of data collection in all stations it ranged between $35-40 \%$ while parameters such as temperature, $\mathrm{pH}$ and Do are still within the tolerance threshold of the quality standard. In addition, the brightness parameter is also very decisive on coral growth. Sedimentation or deposition that occurs due to various kinds of human activities such as mining, construction along the coast, logging of tropical forests, or agriculture. These activities result in soil erosion that is carried to the sea. Where the research location is in the waters of Sungai Cuka Village, Kintap District is right at the mouth of the Cuka river, as a result the level of turbidity of the water can also lead to higher and threaten the life of existing coral reefs because the water quality is dirty and cloudy, this can be seen in the data obtained that the brightness parameter only reaches 3 3.5 meters, only at station 3 which has a brightness of 5.2 meters. it can be concluded that the lower the level of brightness of a waters, it will be able to disrupt the growth of corals.

The average current velocity is $0.07 \mathrm{~m} / \mathrm{s}$ with the highest value at station 3 being 0.10 $\mathrm{m} / \mathrm{s}$ in Table 6. The current velocity value in Table 12 shows results greater than the current velocity in the coastal waters of Angsana Regency. Soil seasoning between $0.01-0.05 \mathrm{~m} / \mathrm{s}$ with an average of $0.03 \mathrm{~m} / \mathrm{s}$ (Iskandar\& Tony, 2013). Currents play a role in the growth process to supply food in the form of plankton, oxygen and are needed in the cleaning process of materials stuck in coral polyps (Dahuri, 2003). So, the condition of the corals will be better if they are in areas with moderate currents because they do not make the corals break easily and help clean the material on the corals. In addition, currents are also able to reduce sedimentation that covers the coral surface. Based on the data above, the range of current velocity also affects the growth of coral reefs. This is in line with the condition of clam coral cover in the Kima reef waters area in the village of Bunati district, Angsana Regency. Ground seasoning with fair to good category (Jainudin, et al, 2015), while in the research area it is categorized as lo to fair.

The abundance of algae living on coral reefs is not a good indication. Algae that grow because of the amount of pollution that occur makes the condition of coral reefs gradually die. Moreover, if the algae-eating fish are caught in excess, it is certain that the algae will grow rapidly because the algae-eating fish are decreasing. All stations in the research location were found with Halimidae Algae. The dominance of soft coral cover and algae causes space competition with hard corals and inhibits the coral recruitment process by preventing the attachment of larvae and the development of coral seedlings (Loya et al., 2004). Hard corals and soft corals are important benthic reef communities, both of which often coexist as sessile benthic species that compete with each other for space. The dominance of soft corals is benefited by waters with high nutrient waves and fairly strong currents and low temperatures, which occur regularly and continuously (Rustam et al., 2016).

\section{CONCLUSION}

Coral reef ecosystems around the waters of Sungai Cuka village, KintapDistrict only found 1 type of Acropora coral lifeform, namely Acropora tabulate (ACT), and 4 NonAcropora species namely Coral branching (CB), Coral massive (CM), Coral encrusting (CE), Coral foliose (CF), Coral reef cover range life ranged from low to fair.

Almost all water quality parameters measured are: temperature, brightness, current speed, salinity, $\mathrm{pH}$ and DO are still within the tolerance limits of water quality standards, except for brightness which is below the quality standard threshold and salinity is above the quality standard threshold based on Indonesia Environment Minister's Decree No 51/2004.

\section{ACKNOWLEDGMENTS}

The authors would like to thank the Government of Tanah Laut Regency, South Kalimantan Province for supporting and facilitating this research. The authors also thank the Dean of the Faculty of Fisheries and Marine, LambungMangkurat University and the Dean of the Faculty of Agriculture, Ahmad Yani University and also all friends who have supported so that this research can be completed. 


\section{REFERENCES}

1. Bengen, D.G., 2002, Sinopsis Ekosistem Sumberdaya Alam Pesisir dan Lautserta Prinsip Pengelolaannya, Bogor, Pusat Kajian Sumberdaya Pesisir dan Lautan, Institut Pertanian Bogor.

2. Bengen, DG dan ASW. Retraubun. 2006. MenguakRealitas dan Urgensi Pengelolaan Berbasis Eko-Sosio Sistem Pulau-pulau Kecil. Jakarta: Pusat Pembelajaran dan Pengembangan Pesisir dan Laut (P4L).

3. Coralwatch. 2011. Terumbu Karang dan Perubahanlklim. Panduan Pendidikan dan Pembangunan Kesadartahuan. The University of Queensland. Australia, 272 hal.

4. Connell, J.H., 1978. Diversity in tropical rainforests and coral reefs. Science 199: 1302 1310.

5. Dahuri, R. 2001. Analisis Daya Dukung Kawasan Pesisir dan laut. Bahan Kuliah: Analisis Sistem Permodelan. Bogor: Institut Pertanian Bogor.

6. Dahuri, R. 2003. Keanekargaman Hayati Laut Pembangunan Berkelanjutan Indonesia. Jakarta: Gramedia Pustaka Utama

7. English, S., Wilkinson, C., Baker, V., 1994. Survey Manual for Tropical Marine Resources. ASEAN - Australia Marine Science Project Living CoastalResources. Australia.

8. English S., C. Wilkinson \& V. Baker, 1997. Survey Manual for Tropical Marine Resources, 2nd Edition. (Townsville: Australian Institute of Marine Science).

9. Fabinyi, M. 2008. Dive tourism, fishing and marine protected areas in the Calamianes Islands, Philippines. Marine Policy 32: 898 - 904

10. Fadli, N. 2008. Tingkat Kelangsungan Hidup Fragmen Karang Acropora Formosa yang ditransplantasikan pada media buatan yang terbuatdaripecahankarang (Rubble). BeritaBiologi 9(3) 2008: pp 265-273

11. Giyanto, Abrar M, Hadi TA, Budiyanto A, Hafizt M, Salatalohy A, Iswari M. 2017. Status TerumbuKarang Indonesia 2017. Jakarta: LIPI Press.

12. Gomez ED, Alcala AC. 1982. Survey of Philipine coral reefs using transect and quadrat techniques. Dalam: UNESCO. 1984. Comparing coral reef survey methods. Report of region UNESCO/UNEP workshop, Phuke Marine Biological Centre, Thailand, 13-17 Desember 1982. UNESCO Reports in Marine Science 21:57-69.

13. Haris, A. 2011. Tranplantasikarang Acroporidea Pada Substrat Alami, Omni Akuatika X (12) 2011: pp33-42

14. Haruddin. A., Edi. P, dan Sri B. 2011. Dampak Kerusakan Ekosistem Terumbu Karang Terhadap Hasil Penangkapanlkan Oleh Nelayan Secara Tradisional Di Pulau Siompu Kabupaten Buton Propinsi Sulawesi Tenggara. Jurnal EKOSAINS. Vol. III.No. 3. Dinas Pendidikan Kabupaten Buton, Sulawesi Tenggara, Prodi IImu Lingkungan Pascasarjana Universitas Sebelas Maret; Surakarta.

15. Hidayat A. S., and Agusliani, E., 2020. Beach tourism, whether benefit or disaster forcoastal fishermen of Tanah Laut Regency, South Kalimantan Province. AACL Bioflux, 2020, Volume 13, Issue 3.

16. Rifa'i, M.A (2016). The Abundance and Size of Giant Sea Anemones at different Depths in the waters of Teluk Tamiang Village. South Kalimantan. AACL Bioflux 9(3): 704-712.

17. Rifa'i, M.A., Fatmawati, Tony, F., Kudsiah, H (2016). The Survival and Growth Rate of Three Species of Sea Anemones from Asexsual Reproduction in PulauKerumputan and Pulau Karayaan. Indonesia. EEC 22(3): 1523-1531.

18. Iskandar, R., Soemarno, Kusuma, Z., Wiadnya, D, G, R. 2020., Coral Reef Condition With Chaetodontidae Fish As The Indicators In The Waters Of The SamberGelap Island Of Kotabaru, South Kalimantan., DOI https://doi.org/10.18551/rjoas.2020-11.10

19. Iskandar, R., Soemarno, Kusuma, Z., Wiadnya, D, G, R. 2020., Association between Coral Community Coverage with Coral Reef Fish Communities at Samber Gelap Island, South Kalimantan, Indonesia. Egyptian Journal of Aquatic Biology \& Fisheries Zoology Department, Faculty of Science, Ain Shams University, Cairo, Egypt. ISSN $1110-6131$ Vol. 25(3): $861-881$ (2021) 
20. Iskandar, R., Tony. F., 2013. Studi Sedimentasi Dimuara Sungai Angsana Kecamatan Angsana Kabupaten Tanah Bumbu Kalimantan Selatan, Enviro Scienteae 9 (2013) 106111 , ISSN 1978-8096.

21. Jainuddin, dkk., 2015. Kondisi Tutupan Terumbu Karang Kima Di Kawasan Perairan Desa Bunati Kecamatan Angsana Kabupaten Tanah Bumbu Provinsi Kalimantan Selatan. Fish Scientiae, Volume 5 Nomor 10, Desember 2015, hal 122-122

22. Johan, O. 2012, The Survival of Transplanted Coral on Pyramid-shape Fish Shelter on the Coastal Water of Kelapa and Harapan Islands, Kepulauan Seribu Jakarta. Indonesian Aquaculture Journal 7 (1) 2012: pp79-85

23. [KepMen LH] Keputusan Menteri Lingkungan Hidup. 2001. Keputusan Menteri Negara Lingkungan Hidup Nomor. 4 Tahun 2001. Tentang Penilaian Kondisi Terumbu Karang. Kementerian LingkunganHidup. Jakarta.

24. [KepMen LH] Keputusan Menteri LingkunganHidup. 2004. Keputusan Menteri Negara LingkunganHidupNomor 51 Tahun 2004 Tentang Baku Mutu Air Laut. Jakarta: Kementerian LingkunganHidup press.

25. Loya Y, Lubinevsk H, Rosenfeld M, Kramarsky-Winter E. 2004. Nutrient enrichment caused by in situ fish farms at Eilat, Red Sea is detrimental to coral reproduction. Mar Pollut Bull. 49(4):344-353.

26. Madduppa, H.M., Subhan, B., Bachtiar R., Ismet, M.S., Budikartini,Y.,Bria,M.D.2008. Prospek Terumbu Buatan Biorockdalam Peningkatan Sumberdayalkandi Kepulauan Seribu. Prosiding Munas Terumbu Karang 2007, Program Rehabilitasi Terumbu Karang COREMAP II, (hlm 68-76), 10-11 September 2007 Departemen Kelautan dan Perikanan.

27. Mismail, B. 2010. Akuarium Terumbu Karang. Cetakan Pertama. Malang: Universitas Brawijaya Press (UB Press).

28. Nontji. A. 1993. Laut Nusantara. Djambatan. Jakarta, 367 hal.

29. Nybakken, J.W. 1988. Biologi Laut: Suatu Pendekatan Ekologi (alihbahasadari Marine Biology: An Ecologycal Approach, Oleh: M. Eidman, Koesoebiono, D.G. Bengen, M.Hutomo, dan S. Sukardjo). PT Gramedia. Jakarta

30. Nybakken, J.W. 2000.Biologi Laut Suatu Pendekatan Ekologi. PT.Gramedia. Jakarta

31. Oktarina, A., E. Kamal dan Soeparno. 2014. Kajian Kondisi Terumbu Karang dan Strategi Pengelolaannya di Pulau Panjang, Air Bangis, Kabupaten Pasaman Barat. Program PascasarjanaUniversitas Bung Hatta.

32. Romimohtarto K., S. Juwana., 2005. Biologi Laut, Ilmu Pengetahuan Tentang Biota Laut. Cet. Keduaed. revisi. Djembatan.Jakarta

33. Rustam A, Yulius A, Heriati, Salim HL, Ramdhan M. 2016. Kajian kualitas air perairan Lombok Tengah sebagaikawasan konservasi lautdaerah. Taslim Arifin et al (eds). Bunga Rampai: Iptek Sumberdaya Pesisir Untuk Pengembangan Blue Economy di Pulau Lombok. IPB Press. Bogor.

34. Sadarun, B., E. Nezon, S. Wardono, Y. A. Afandy dan L. Nuriadi. 2006. PetunjukPelaksanaanTransplantasiKarang. DepartemenKe-lautan dan Perikanan. Jakarta 36 hal.

35. Subhan, B., Soedharma, D., Madduppa, H., Arafat, D., Heptarina, D. 2008. Kelangsungan Hidup dan Pertumbuhan Karangjenis Euphylliasp, Plerogyrasinuosa dan Cynarina lacrymalis yang ditransplantasikandi Pulau Pari, Kepulauan Seribu, Jakarta. Prosiding Seminar Nasional Penelitian-penelitian Kelautan dan Perikanan, (hIm59-61), 8 November 2008. Universitas Brawijaya.

36. Suharsono, 1996. Jenis-JenisKarang Yang Umum di Jumpai di Perairan Indonesia. P3OLIPI. Jakarta

37. Suharsono, 1998. Condition of Coral Reef Resources in Indonesia. Jurnal Pesisir dan Lautan. 1(2): 1998. 44-52.

38. Sukarno, 1993. Mengenal Ekosistem Terumbu Karang. LIPI. Jakarta.

39. Supriharyono. 2000. Pengelolaan Ekosistem Terumbu Karang. Penerbit Djambatan. Jakarta. 118 hal

40. Supriharyono. 2007. Konservasi Ekosistem Sumberdaya Hayati di Kawasan Pesisir dan Laut Tropis. Pustaka Pelajar. Yogyakarta. 
41. Timotius, Silvianita. 2003. Biologi Terumbu Karang. Yayasan Terumbu Karang Indonesia

42. Timotius, S., 2006. Biologi Karang. Terangi.

43. Tony, F., Soemarno, Wiadnya, D, G, R., Hakim, L. 2020., Diversity of reef fish in HalangMelingkau Island, South Kalimantan, Indonesia., Biodiversitas ISSN: 1412-033X Volume 21, Number 10, October 2020 E-ISSN: 2085-4722, Pages: 4804-4812

44. Tony, F., Soemarno, Wiadnya, D, G, R., Hakim, L. 2021., Habitat Biodiversity as a Determinant of Fish Community Structure on Coral Reefs in HalangMelingkau Island, Kotabaru, South Kalimantan, Indonesia., Egyptian Journal of Aquatic Biology \& Fisheries Zoology Department, Faculty of Science, Ain Shams University, Cairo, Egypt. ISSN 1110 -613 Vol. 25(1): 351 - 370 (2021).

45. Tony F., Iskandar Rina., Rifa'l M. Ahsin., Khasanah R. I. 2021., Effectiveness of Bioreef_Block Technology on Reef Fish Diversity In Marine Waters Of Sungai Cuka Village At Kintap District, Tanah Laut Regency of South Kalimantan, Indonesia. DOI 10.18551/rjoas.2021-07.24

46. Veron JEN, 1986. Corals of Australia and The Indo - Pasifi c. Angus And Robertson Publisers.

47. Veron, J. E. N. 1995. Corals in space and time: biogeography and evolution of Scleractinia. Australia Institute of Marine Science. Cape Ferguson, Townsville Queensland.

48. Yusri, Safari. 2011. Pengenalan Bentuk Pertumbuhan Karang Dan Struktur Rangka Kapur Karang. Terangi.

49. Zamani, N. P., Subhan, B., Madduppa, H., Bachtiar, R., Destianto, M., Maulina T., 2009. Pengaruh Biorockterhadap Keragaman dan Kelimpahanlkan Karang di Tanjung Lesung, Banten. ProsidingSimposiumNasionalTerumbuKarang II. Program Rehabilitasi dan PengelolaanTerumbuKarang CORMAP II. (hlm 158-163), 19-20 November 2008. DirektoratJenderalKelautan dan Pulau-pulau Kecil DepartemenKelautan dan Perikanan

50. Zhiyong F, Sheng Z. 2009. Research on psychological carrying capacity of tourism destination. Chinese Journal of Population 7 (1): 47-50. 